\title{
SUCCESSFUL TALENT MANAGEMENT THROUGH POSITIVE CSR-DRIVEN TRANSACTIONS
}

\author{
Adrian Pyszka ${ }^{a}$, Daniel Gajda \\ University of Economics in Katowice, \\ Department of Human Resource Management, Katowice, Poland \\ a e-mail: adrian.pyszka@ue.katowice.pl \\ be-mail: daniel.gajda@ue.katowice.pl
}

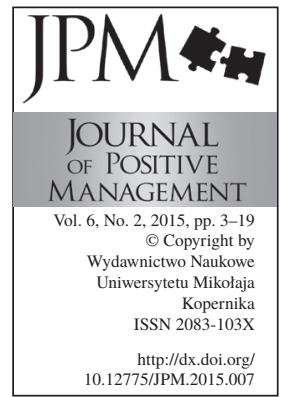

\begin{abstract}
Purpose: The purpose of this paper is to study the meaning of talent management (TM) in the context of corporate social responsibility (CSR) and transaction cost theory (TCE).

Approach: This is a literature review paper.

Findings: The study suggests that, contrary to economical predictions, TM is a socially unpredictable process that has to be based on a clearly articulated and contingent input-output perspective provided by positive CSR strategies. This study shows (against a backdrop of the boundaries of the socially responsible organization) the transactional nature of talent management and highlights the issues that affect the process of talent acquisition, development and retention. The study proposes a CSR driven talent management model, to fill the gap between talent management processes and organization development requirements, that enhances in-house talent satisfaction, engagement and commitment talented employees to continue employment as well as attracting outside talents to the organization.
\end{abstract}

Research limitations: This study is based on theoretical analysis and its assumptions should be tested empirically.

Practical implications: The study shows the need for integration of the CSR practices and talent management to decrease transaction costs. The study stresses that CSR-driven TM has to consider the initial growth of transaction costs and their decline at the end of the TM process.

Originality/Value of the paper: The study addresses a research gap by integrating TM with CSR and TCE perspectives. It is also suggested that instead of well-developed talent management processes companies have to consider striking a balance between profitability and responsibility to find an appropriate regulator of the future transactions.

Keywords: human resource management, talent management, corporate social responsibility, transaction costs, model

Paper type: Conceptual paper 
SUCCESSFUL TALENT

MANAGEMENT

THROUGH POSITIVE

Adrian Pyszka

Daniel Gajda

\section{Introduction}

Talent management means using an integrated set of activities to ensure attracting, retaining and developing the talented people that a company needs for future purposes (Vladescu, 2012). We could ask why TM has become one of the most important processes of organizational success - more important than money, market share and management team? According to Ulrich and Smallwood (2002), many of today's businesses believe that "winning the war for talent ensures that competent and committed employees are placed throughout a firm".

New approaches to work, especially flexible approach to working patterns, may empower employees to exercise some direction over when, where and how they work, and employers to become the employer of choice. As stated by Pilbeam and Corbridge (2002), this is a new challenge for both sides of contract, when employees compare personal circumstances and work demands, and employers try to benefit from improved employee effectiveness and performance, as well as the recruitment and retention of talented workers.

Flexibility at work and on the job market is totally changing traditional approaches to work, with organization based on hierarchy, control, structures and job descriptions. Nowadays, dynamic environments require more organic management and pursuit of flexibility (Pilbeam and Corbridge, 2002). This could be important to recognize talented people (in-side and outside) that could work for our organization. Atkinson (1984) claimed that a flexible firm divides the workforce into a core group (primary labour market), primary and secondary peripheral group and others (temporary, self-employment, outsourcing and sub-contracting).

This is a new organizational reality where HR and organizational leaders have to consider the following issues: how to recognize and attract talented people, how to cooperate with them and what kind of incentives could retain these people in a given organization? It seems to be important to look at the relationship between different approaches to talent recognition and management in the context of the growing flexibility and requirements for corporate social responsibility, but keeping the sight of performance and costs of the transactions mentioned above. According to Grant Thornton International Business Report (2008), there are indications to claim that a well-developed performance and talent management strategy with embedded CSR components can reduce the likelihood and impact of losing employees, especially in privately held businesses were CSR initiatives have to be implemented in their workforce recruitment and retention issues.

Based on literature preview, authors try to find answers to the following research questions:

1) What issues have significant impact on TM?

2) Why is CSR important in TM process?

3) How to get positive value using transaction costs guidance due to responsible TM process? 
Besides talent management processes and their conditions, authors argue that CSR is a key moderator posing restrictions on talent management, that may limit some services and groups of stakeholders (outside talented professionals, employment agencies, headhunters, training companies, outsourcing companies

SUCCESSFUL TALENT MANAGEMENT THROUGH POSITIVE

Adrian Pyszka Daniel Gajda etc.). This is because of i.e. ethical and shared value creation restrictions which may rise transaction costs (Midttun, 2005). On the other hand, CSR are giving a chance to use challenges and values to prepare programs, meaningful and of better quality, to engage talented employees and meet their expectations.

\section{Traditional view on talent management (TM) in an organization}

\subsection{The essence of talent management}

It is widely recognized that 80 's and 90's of twentieth century mark a date of birth and development of the talent management idea, when American companies acknowledged the significant lack of professionals and employees who could replace retiring managers (Tabor, 2013). However, it is hard to imagine that never before has anyone thought about outstandingly talented employees.

The notion described became very popular in the late 90's, when the McKinsey consulting company released the findings which indicated that the most successful organizations had leaders awfully focused on talents (Burkus and Osula, 2011). These organizations would identify and hire top performers in hope that this was the key to outperforming the competitors. Moreover, McKinsey experts have defined a new business reality, which they called "war for talent" intense competitive battle between organizations for talented employees (Michaels et al., 2001).

R. E. Lewis and R. J. Heckman (2006), based on their literature review, contend that definitions of talent management fall into one of three broad streams, i.e.: TM as HRM, TM focused on the concept of talent pool and TM centered on talent.

The first stream views TM as a combination of typical human resource management practices, functions and activities, such as recruitment, selection, development, succession planning, etc. (Burbach and Royle, 2010). According to authors representing this stream, talent management requires following the patterns of HR departments' routines, but faster (via Internet, outsourcing) or across the whole enterprise rather than within a department or function. Authors also suggest that the term itself, "human resource management", will be replaced by the term "talent management" in the future (Lewis and Heckman, 2006).

The second category of definitions focuses primarily on creation of large talent pools, in order to ensure the qualitative and quantitative flow of talented employees through the organization (Burbach and Royle, 2010). This approach is typically built on principles of succession planning or human resource planning 
SUCCESSFUL TALENT

MANAGEMENT

THROUGH POSITIVE

Adrian Pyszka

Daniel Gajda
(Jackson and Schuler, 1990; Rothwell, 1994), but can also include typical HR practices and processes (e.g. recruitment, selection). The core of this approach is a projection of an employee's needs and managing the progression of employees through positions, often by the use of enterprise-wide software systems. This perspective is focused on internal rather than external resources of the organization (Lewis and Heckman, 2006).

The third category focuses on talent generically. There are two general views on talent emerging from this perspective. The first one regards talent as "an unqualified good and a resource to be managed primarily according to performance levels" (Lewis and Heckman, 2006). It means that highly competent performers should be sought, hired and differentially rewarded regardless of their specific role or organization's specific needs. Thus, in comparison to the previous perspective, organizations are encouraged to manage performance pools of talent rather than succession pools for specific jobs (Lewis and Heckman, 2006). The proponents of this stream classify all employees by a performance level (e.g. "A" - best, "B" - good, "C" - bottom performers) and either encourage rigorously terminating bottom performers (Axelrod et al., 2002) or "topgrading" the organization by hiring exclusively the best performers (Smart, 1999) [1]. Other authors view talent as "an undifferentiated good and emerges from the both the humanistic and demographic perspectives" (Lewis and Heckman, 2006). In this approach talent is critical because, on the one hand, the role of a strong HR function is to manage everyone to a high performance (Buckingham and Vosburgh, 2001) and, on the other hand, demographic and business trends make talent more valuable (Gandossy and Kao, 2004; Tucker et al., 2005).

\subsection{Key components of talent management}

In order to indicate key components of talent management authors revied and analysed of TM models described in scientific literature. The TM model outlines the sequence of steps to be followed to effectively implementa talent management strategy (Mehta, 2011). It provides HR practitioners with a framework to manage talent within their organizations. With regard to the fact that process of talent management is a very 'personal' matter for an organization, because it should be adjusted to the organization's needs and expectations, there is no single, generally accepted TM model (Chodorek, 2012). The components of TM model may vary by type and scale of the activity, strategic assumptions, size of the budget, organizational maturity, organizational culture etc. (Bingham, 2008). Also, diversity management requires the implementation of different TM models regarding different groups of talented employees, e.g. young people, managers, specialists (Borkowska, 2005). The results of conducted TM models analysis are presented in Table 1. 


\begin{tabular}{|c|c|c|c|}
\hline & $\begin{array}{l}\text { Com- } \\
\text { ponents } \\
\text { group }\end{array}$ & \multicolumn{2}{|c|}{ Examples of TM components } \\
\hline \multirow[t]{8}{*}{ 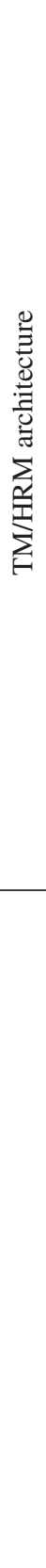 } & $\begin{array}{l}\text { Talent ma- } \\
\text { nagement } \\
\text { activities, } \\
\text { practices } \\
\text { and func- } \\
\text { tions }\end{array}$ & \multicolumn{2}{|c|}{$\begin{array}{l}\text { - Employee relations management, rewarding and recognition, performance } \\
\text { management, diversity management, career and HR development, organi- } \\
\text { zational development (Christensen, 1997). } \\
\text { - Hiring, removal (fire, rotate, demote), retention, development and lear- } \\
\text { ning, communication (Ashton and Morton, 2005). } \\
\text { - Attracting, selecting, engaging, developing, retaining, execution, evalu- } \\
\text { ation (Phillips and Roper, 2009). } \\
\text { - Identification, attracting, integrating and measuring, developing, rewar- } \\
\text { ding of talents (Areiqat et al., 2010). } \\
\text { - Recruitment and selection, development and training, performance mana- } \\
\text { gement, retention, compensation and rewards, talent review (Stahl et al., } \\
\text { 2012). } \\
\text { - Workforce planning, talent acquisition, performance management, training } \\
\text { and development, retention and engagement, succession planning and } \\
\text { knowledge transfer (Brown, 2014). }\end{array}$} \\
\hline & $\begin{array}{l}\text { Core of } \\
\text { the pro- } \\
\text { cess }\end{array}$ & \multicolumn{2}{|c|}{$\begin{array}{l}\text { - Organization's values, competencies (Christensen, 1997; Phillips and } \\
\text { Roper, 2009). } \\
\text { - Leader-manager competencies: interpersonal, political, operational, deve- } \\
\text { lopmental, strategic (Brown, 2014). }\end{array}$} \\
\hline & $\begin{array}{l}\text { Guiding } \\
\text { principles }\end{array}$ & \multicolumn{2}{|c|}{$\begin{array}{l}\text { Alignment with strategy, internal consistency, management involvement, } \\
\text { employer branding through differentiation, balancing global and local } \\
\text { needs, cultural embeddedness (Stahl et al., 2012). }\end{array}$} \\
\hline & \multirow[t]{2}{*}{ Outcomes } & $\begin{array}{l}\text { at organizational } \\
\text { level }\end{array}$ & $\begin{array}{l}\text { - Firm performance (Collings and Mellahi, 2009). } \\
\text { - Business results (Areiqat et al., 2010). } \\
\text { - Organizational performance: innovation, learning and } \\
\text { growth (Majeed, 2013). }\end{array}$ \\
\hline & & $\begin{array}{l}\text { at individual } \\
\text { level }\end{array}$ & $\begin{array}{l}\text { - Work motivation, organizational commitment, extra } \\
\text { role bahaviour (Collings and Mellahi, 2009). }\end{array}$ \\
\hline & \multirow{3}{*}{ Context } & Global & - Global economy, global politics (Brown, 2014). \\
\hline & & National & $\begin{array}{l}\text { - Business environment (Christensen, 1997). } \\
\text { performance driven, foreign influence, philosophy and } \\
\text { religion (Brown, 2014). }\end{array}$ \\
\hline & & Organizational & $\begin{array}{l}\text { - Business vision, strategies, priorities and goals (Chri- } \\
\text { stensen, 1997). } \\
\text { - Organizational climate - values, leadership, structures, } \\
\text { policies, processes (Ashton and Morton, 2005). } \\
\text { - Business strategy, talent strategy (Areiqat et al., 2010). } \\
\text { - Organizational culture (Brown, 2014). }\end{array}$ \\
\hline
\end{tabular}

SUCCESSFUL TALENT

MANAGEMENT

THROUGH POSITIVE

Adrian Pyszka

Daniel Gajda
Hiring, removal (fire, rotate, demote), retention, development and learning, communication (Ashton and Morton, 2005).

nagement activities, practices and functions

- Workforce planning, talent acquisition, performance management, training and development, retention and engagement, succession planning and (Brown, 2014).

Organization's values, competencies (Christensen, 1997; Phillips and Roper, 2009)

Guiding principles needs, cultural embeddedness (Stahl et al., 2012)

- Firm performance (Collings and Mellahi, 2009).

Organizational performance: innovation, learning and growth (Majeed, 2013). role bahaviour (Collings and Mellahi, 2009).

- Business environment (Christensen, 1997). performance driven, foreign influence, philosophy and stensen, 1997). policies, processes (Ashton and Morton, 2005).

- Organizational culture (Brown, 2014).
Table 1. Key components of talent management 
SUCCESSFUL TALENT

MANAGEMENT

THROUGH POSITIVE

Adrian Pyszka Daniel Gajda
Five groups of key TM components have been identified: (1) talent management activities, practices and functions, (2) core of the TM processes and (3) guiding principles which constitute the elements of TM/HR architecture, as well as (4) talent management outcomes and (5) the context.

It is important to note that most authors (table 1) perceive talent management in the process perspective, because it can be easy depicted as logical connections and relationships. Furthermore, authors include components such as rotation among different workplaces (e.g. Ashton and Morton, 2005) or long-range development plans (e.g. Christensen, 1997; Stahl et al., 2012; Brown, 2014), so we can guess that talent management process is focused on young and dynamic employees, because it is difficult to relate mentioned elements to older people. We also observed that many authors of TM models, unfortunately, ignore the problem of talents departures. It is surprising, because departures of talented employees will happen sooner or later and lack of talent retention practices can impede or even paralyse organization's activity.

\section{Corporate Social Responsibility (CSR) and their transactional nature}

There is a continuous discussion about CSR and their role in a company. Let us begin with Friedman's (1970) disputable statement that company is socially responsible only for one thing "(...) to use its resources and engage in activities designed to increase its profits so long as it stays within the rules of the game, which is to say, engages in open and free competition without deception or fraud".

The most popular model of CSR is the Carroll (1974) after-profit obligation, referring to the pyramid of four responsibility levels with the assumption that the key is economic responsibility, which is connectedwith the firm's performance. On the next levels of responsibility, we find expectations placed by society and considered a legal, ethical and philanthropic responsibility. Interpretation of this model suggests that those companies which are not profitable do not have to behave responsibly. An alternative model "before-profit obligation" (Kang and Wood, 1995) is turning economic paradigm upside down where the main responsibility is the one to stakeholders.

Kotler and Lee (2005) claim that CSR “(...) is a commitment to improve community well-being through discretionary business practices and contributions of corporate resources". As they stated, the key word is "discretionary" which refers to an additional, not mandated by law but voluntary commitment a given business makes when making these contributions.

CSR is a stakeholder-oriented concept (Maon et al., 2009) because it extends beyond the organization's boundaries and is driven by an ethical understanding of the organization's responsibility for the impact of its business activitieshus, seeking in return society's acceptance of the legitimacy of the organization. 
According to Waddock and Bodwell (2007), CSR is associated with corporate citizenship and goes beyond traditional 'do good', philanthropy and volunteerism. They articulated that managing the responsibility means building trust and cooperation with the key stakeholders, both inside and outside the company, to reduce negative impact and develop positive and beneficial practices and ways of interacting, using natural resources in a sustainable way. They argue (Waddock and Bodwell, 2007) that awareness of the concerns and interests of stakeholders can enhance the company performance and decision-making processes.

This approach is close to a paradigm shift (Porter and Kramer, 2006) from responsive CSR (reactive, chaotic, lack of analysis, ad hoc CSR activity, shortterm initiatives) to proactive (anticipative, focused on goals, with transferring resources between social and business partners, oriented on long-term and planned CSR activities, focused on innovations).

In the literature there are models with different CSR implementation directions, top-down and bottom-up. The top-down models see CSR as a part of organizational strategy introduced by managers (Sharp and Zaidman, 2010). The bottom-up models are more employee orientated (Nord et al., 2009) and they perceive CSR is an emerging strategy (Maon et al., 2009). Although CSR requires a deliberate course of action, many organizations do not think about the strategy of CSR. According to Hollender and Brenn (2010), revolution in the corporate social responsibility is inside-out by changing the image of the organization through: the implementation of innovative models of work, the creation of a new logic of competition, finding other methods of leadership and redefining business objectives. As stated by Porter and Kramer (2006), CSR policy contributes to obtaining the 'shared value' by the ability to fit between the value chain and social dimensions of competitive context [2]. For application purposes Porter and Kramer (2011) have created a wider concept of 'Corporate Social Value' (CSV) that guides the company's investment in the community to create economic value by creating social value [3].

As stated by Hollender and Brenn (2010), there is something even $m$ and more vital than responsibility which is called "corporate consciousness". Conscious companies have knowledge at an individual or organizational level, with clearly articulated knowledge of what matters to the company and their stakeholders, in day-to-day decision making, with conscious leaders and intended impact on society and organization itself.

Gond et al. (2011) investigated how Human Resources departments contribute to responsible leadership at different levels of analysis. They found that implementation and integration of CSR bring about cultural changes, the adoption of different work practices, that link employee rewards with socially responsible behaviors, iterative learning and management, and awareness of stakeholders. At the Figure 1 there are three categories of CSR-HR practices.

SUCCESSFUL TALENT

MANAGEMENT

THROUGH POSITIVE

Adrian Pyszka Daniel Gajda 
SUCCESSFUL TALENT

MANAGEMENT

THROUGH POSITIVE

Adrian Pyszka

Daniel Gajda

Figure 1.

Investigation in linking CSR-HR activity

Source: own elaboration on the basis of: (Gond et al., 2011).

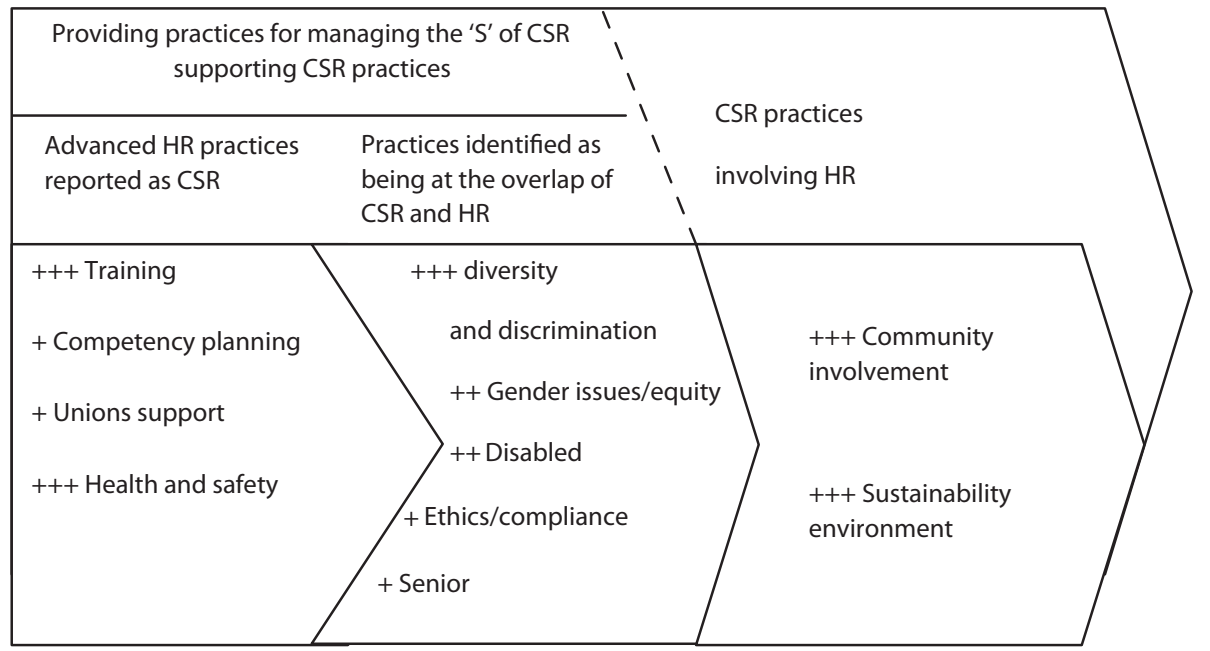

+++ indicated by respondents above-average interest in a CSR \& HR factor

To meet this challenge HR people, have to take CSR agenda seriously because of increasing company's impact on society and employees, which are key organizational stakeholders.

According to stakeholder's theory and practices, companies that take into account the interests of stakeholders are more likely to behave responsibly and can successfully create values, both commercial and social. That kind of value can strengthen stakeholder loyalty and corporate resilience and its transparent supplementation icould lead to greater organizational identity and efficiency (Wheeler and Sillanpää, 1997). Companies involved in repeated transactions with stakeholders on the basis of trust and cooperation are motivated to be honest, trustworthy, and ethical because of high returns to such a behavior (Jones, 1995).

In the literature researchers mainly focus on the economic aspects of transactions and haven't paid attention to more behavioral aspects of the transactions, especially the justice in the economic exchange, involving the lowering transaction costs (Husted and Folger, 2004).

Transaction costs theory (TCE) is a result of development of the new institutional economy (NIE), which is critical to the neoclassical theory of the company that limits organization to "black-box" (Paauwe and Boselie, 2003). The new institutional look at a company forcing social context of the transaction exp. tradition, pressure on the regulation and network relations, concerning decisions on choice of resources during negotiating planned contracts. Context, particularly the cultural one, is important when a company tries institutionalizing CSR (Pyszka 
and Piłat, 2011). It seems essential from the point of view of responsible talent management, where costs - as well as effects - are important for later success and increasing competitiveness of the organization.

Transaction costs theory, created by Coase (1937), widens the company borders. Coase argued that markets and hierarchy are alternative regulating structures moderated by transactional costs. In his articles Williamson (2010) demonstrated that companies can differentiate their level of effectiveness using alternative hierarchic or marketplace regulations. He claimed that major factors which control transactions depend on assets specify, frequency of transactions and the level of uncertainty. Other authors (Jones and Hill, 1988) indicate bounded rationality that limits an individual's knowledge and cognitive facility to process information. According to Williamson (1998), the time of cost creation determines the division into two main groups of costs: ex-ante and ex-post. Exante costs arise in the preparation phase of the transaction (costs of designing, negotiating and securing contracts). Ex-post costs are associated with monitoring and enforcement of contract terms (costs of inadequacy and renegotiate contract, current costs associated with the governance structure, and cost of storing securing performance of obligations).

As indicated by Husted and Folger (2004), hierarchical mechanism as a regulator could have a problem with assessing the justice of exchange. They introduced the notion of interactional justice which is a component of organizational justice, concerning in particular the way of communication and treatment of employees by managers, such as communication dynamics, truthfulness, respect, propriety of questions, justification, and trust.

Considering the above two types of transactions, hierarchical (vertical integration inside the organization) and market regulation (horizontal), Geyskens et al. (2006) argued to resolve a dilemma with transaction performance to make, buy or ally decisions. They found that the effect of relational governance on performance was substantively larger than hierarchical governance, which is insulated from competitive pressure and subject to bureaucratic phenomena. Further explanation is that the relational governance not only minimizes transaction costs, but also creates value in the exchange relationship through superior information sharing.

In opposition to these proposals there is Ghoshal and Moran's concept (1996), critically reviewing the attitude to the market governance and highlighting the value created by the hierarchical regulation. Ghoshal and Moran suggested that organizations are not mere substitutes for structuring efficient transactions when markets fail. The advantage of organizations over markets may lie in leveraging the human ability to take initiative, to cooperate, to learn (using internalization and diversity) and enhance learning and its use to creating innovations and purposive adaptation. As they argued, organizations have to create social context necessary 
SUCCESSFUL TALENT

MANAGEMENT

THROUGH POSITIVE

Adrian Pyszka

Daniel Gajda to build the trust and commitment important for maintaining cooperation, where learning and trust may take the place that in the theory of markets and hierarchies. is occupied by efficiency and opportunism.

Going beyond transactional costs an organization can gain transactional benefits by using alternative governance structures to distinguish itself from traditional market and hierarchy governance structures (Boudreau et al., 2007). This transactional benefits, intangible in nature (social and psychological dimension), can exist on two levels: organizational and individual. An individual person gains transactional benefits from reputation, collegiality, intellectual challenge, skill development, enhanced self-esteem. At an organizational level it depends on the type of regulation. Organization with a market governance structure can benefit from economy of scale or, in a hierarchy governance structure, organization can use economy of scope and benefit from cumulative learning or monopoly power and so loan.

It could be difficult and ineffective to consider corporate social responsibility (CSR) with the transaction cost perspective, because environmental and social issues may indicate a hierarchical integration or market, but with longterm alliances. According to Midttun (2007), focusing on CSR could decrease efficiency through supply chain integration as well as neglect the credibility by contracting with external contractors. Midttun (2007) claimed that CSR could resolve these problems on three levels: 1) strategic - by strategic alignment with CSR forcing ethical standards, procedures and compliance; 2) operational protection of the company's interests through positive and negative clauses in contracts with partners; 3) governance regulation - appropriate CSR standards, guidelines and regulations.

To sum up, when realizing responsible transactions an organization has to take into account the ex-ante and ex-post transaction costs and value considering CSR rules and standards, especially in the social context, to achieve appropriate level of the interactional justice in order to build trust and commitment, and decrease the level of uncertainty and opportunistic behaviors into organization and through interacting partners.

\section{New "CSR driven Talent Management Model" (CSR-TM Model)}

CSR and employee engagement become a strategic imperative. Bhattacharya et al., (2008) highlights that CSR initiatives are important to current and future employees because of three important issues: 1) value proposition - by revealing the organizational values, 2) humanization of the company - as a contributor to the society not only recipient concerned to maximizing profits, 3) emotion booster - by giving something more than paycheck, differentiate the company from other business entities. 
A global study on HR and CSR showed (Thorton, 2008) that the top factor is the need a business to attract and retain high quality staff to meet current and future demands. The study identified that strong employer brand aligned with employee values and concerns is the best way of retaining talent with employees in contrast to staff attrition and staff turnover, which can result in increased operating costs, the loss of business and reduced customer service standards.

According to the assumptions outlined above, HR is concerned with managing people within an organization to create value for the organization and positive work experiences for individuals. What is also important is the proper alignment of the declared value and realized projects to the business activity, and to contribute the implementation of the activities within the social clusters (Pyszka, 2013). Therefore, using CSR is a chance to create shared value (economic and social) which is in opposite to minimize the cost of employee health care coverage and so on.

There are a few models in the literature that integrate CSR and TM. One of the most interesting is the Bhattacharya et al. (2008) model which indicates growing evidence that a company's CSR activities comprise a legitimate, compelling and increasingly important way to attract and retain good employees. Bhattacharya et al. (2008) claimed that effective talent management process should use more bottom-up CSR to involve employees into the new reality rather than wait for their participation. To achieve this goal, the model has to consider seven key factors merged into one process: Input (CSR activity, proximity to CSR activity), Process (needs fulfilled by CSR), Identification, (company characteristics and employee characteristics), Outcomes (internal and external). This approach seems to be very useful but Bhattacharya's model is mainly aimed at proper implementation of CSR assuming that this would properly facilitate the implementation of the TM process and bring the expected results.

According to the figure below the new "CSR-TM model" presented by the authors (Figure 2) assumed these guidelines for CSR but also considered issues related to HR strategy and policies, transaction costs related to the implementation of all phases of talent management, and the use of environmental and stakeholder's challenges as a new source of innovations and development of a new responsible talents.

The assumptions underlying the "CSR-TM model" are presented in accordance with the guidelines of the new EU policy which place the use of CSR into the center of the organizational activity and also refer to changing ways of working and collaboration, which is forcing more flexibility in employment contracts, organizational downsizing and the automation and computerization of many management processes. 
SUCCESSFUL TALENT

MANAGEMENT

THROUGH POSITIVE

Adrian Pyszka

Daniel Gajda

Figure 2. CSR

driven Talent

Management Model

Source: own

elaboration.

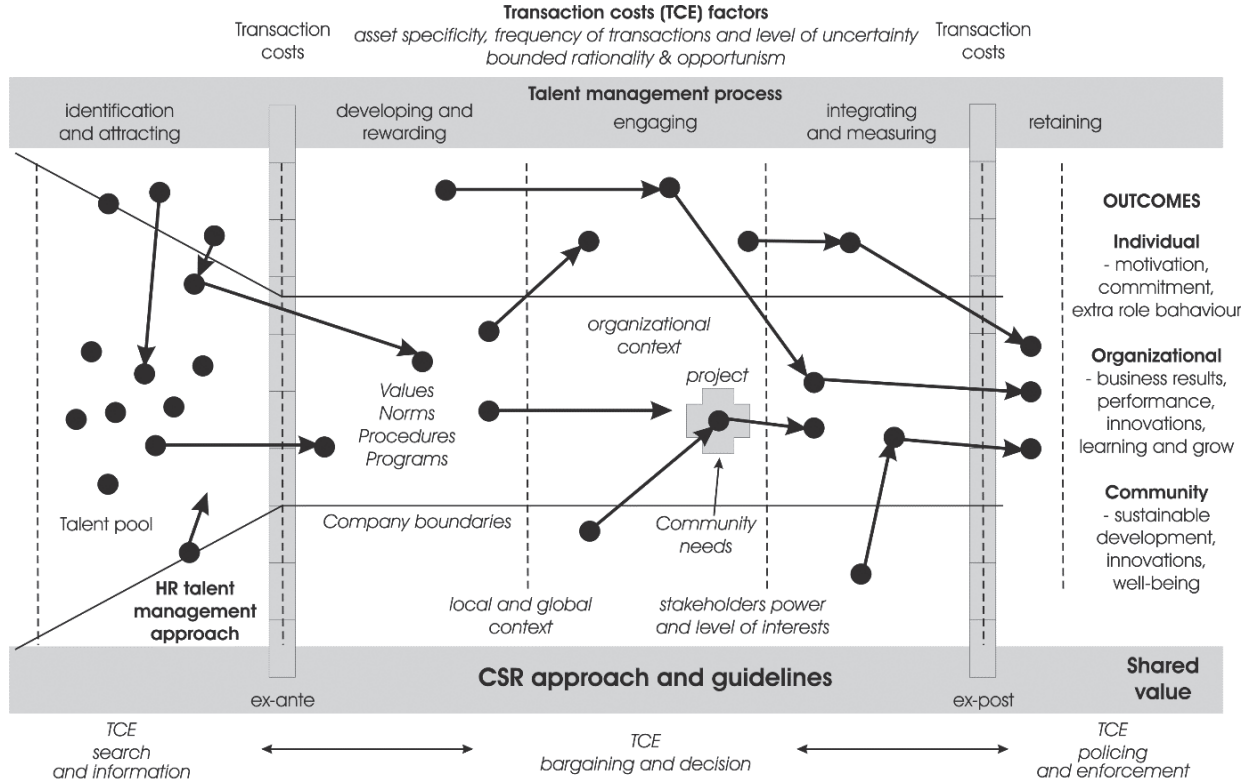

5. Conclusions, limitations and future research

Companies have to shift their CSR management practices with better marketing to be closer to their employees as a main "customers" through optimal CSR strategies especially by increasing employee proximity to CSR, using a contingent inputoutput approach to make CSR decisions, understanding and fulfill employee's needs, strengthen employee identification, involve employees in co-creating CSR value managers (Bhattacharya et al., 2008).

Authors from various fields indicate the possibility and even the necessity to use a few good practices in the area of responsible talent management, e.g.:

- define talent in a broad way, where everyone could be managed to high performance,

- use TM not only for identifying and attracting people, but also for developing, rewarding, integrating, measuring, and retaining the right people into the organization or near to organizational boundaries,

- identify interdependence between a company and society and proactively use TM to develop to maximize shared value,

- be aware of transaction costs, ex-ante and ex-post to choose proper TM actions and sources of talents/candidates and to develop responsible but cost-effective solutions,

- use bottom-up engagement approach to involve all possible talents into the CSR activities, 
- use proactive CSR activities to attract, recruit and develop talented employees,

- measure CSR and TM activities by economic and non-economic indicators (use shared-value approach).

SUCCESSFUL TALENT

MANAGEMENT

THROUGH POSITIVE

Adrian Pyszka

Daniel Gajda

The main limitation of the above study and presented conception is the lack of a broader review of the literature with other socially responsible talent management models. There is also a lack of deeper analysis of the New Institutional Economy (NIE) approach that attempts to extend economics by focusing on the social and legal norms and rules (institutions).

The future research could consider a better exploration of the impact of the transactions on talent management, especially from the perspective of value creation and replacing talent retaining by its better use on the market.

\section{Notes}

[1] Topgrding can be define as "packing entire companies with A players - high performers, from senior management to minimum wage employees - those in the top $10 \%$ of talent for their pay" (Lewis and Heckman, 2006).

[2] Shared value creation focuses on identifying and expanding the connections between societal and economic progress and value is defined as benefits relative to costs, not just benefits (Porter and Kramer, 2011).

[3] CSV is a value orientated activity, with both economic and societal benefits relative to costs (Porter and Kramer, 2011).

\section{References}

Areiqat, A. Y., Abdelhadi, T., Al-Tarawneh, H. A. (2010), "Talent management as a Strategic Practice of Human Resources Management to improve human performance Interdisciplinary", Journal of Contemporary Research in Business, Vol. 2 No. 2, pp. 329-341.

Arthur, J. B., Boyles, T. (2007), "Validating the human resource system structure: A levelbased strategic HRM approach", Human Resource Management Review, Vol. 17 No. 1, pp. 77-92. DOI: http://dx.doi.org/10.1016/j.hrmr.2007.02.001

Ashton, Ch., Morton, L. (2005), "Managing talent for competitive advantage", Strategic HR Review, Vol. 4 No. 1, pp. 28-31.

Atkinson, J. M. (1984), Structures of social action, Cambridge University Press, Cambridge.

Axelrod, B., Handfield-Jones, H., Michaels, E. (2002), "A new game plan for C players”, Harvard Business Review, Vol. 80 No. 1, pp. 80-88.

Becker, B., Gerhart, B. (1996), "The impact of human resource management on organizational performance: Progress and prospects", Academy of Management Journal, Vol. 39 No. 4, pp. 779-801. DOI: http://dx.doi.org/10.2307/256712

Becker, B. E., Huselid, M. A. (2006), "Strategic human resources management: Where do we go from here?", Journal of Management, Vol. 32 No. 6, pp. 898-925.

Bhattacharya, C. B., Sen, S., Korschun, D. (2008), "Using Corporate Social Responsibi- 
SUCCESSFUL TALENT

MANAGEMENT

THROUGH POSITIVE

Adrian Pyszka

Daniel Gajda lity to Win the War for Talent", MIT Sloan Management Review, Vol. 49 No. 2, pp. 37-44.

Bingham, T. (2008), “The Talent Factor”, Public Manager, Vol. 37 No. 3, pp. 80-83.

Bocquet, R., Mothe, C. (2010), "Exploring the relationship between CSR and innovation: A comparison between small and large sized French companies", Revue Sciences de Gestion, No. 80, pp. 101-119.

Borkowska, S. (2005), "Kilka refleksji tytułem wstępu”, in: Borkowska, S. (Ed.), Zarzadzanie talentami, IPISS, Warszawa, pp. 11-15.

Boudreau, J. W., Ranstadt, P. M. (2007), Beyond HR: The new science of Human Capital, Harvard Business School Publishing, Boston.

Brown, L. M. (2014), “A Proposed Talent Management Model for Leader-Managers in State-Owned Enterprises in China", International Journal of Human Resource Studies, Vol. 4 No. 3, pp. 198-213. DOI: http://dx.doi.org/10.5296/ijhrs.v4i3.6011

Buckingham, M., Vosburgh, R. M. (2001), “The $21^{\text {st }}$ century human resources function: It's the talent, stupid!", Human Resource Planning, Vol. 24 No. 4, pp. 17-23.

Burkus, D., Osula, B. (2011), "Faulty Intel in the War for Talent: Replacing the Assumptions of Talent Management with Evidence-based Strategies", Journal of Business Studies Quarterly, Vol. 3 No. 2, pp. 1-9.

Cameron, K. S., Dutton, J. E., Quinn, R. E. (2003), “An Introduction to Positive Organizational Scholarship”, in: Cameron, K. S., Dutton, J. E., Quinn, R. E. (Eds.), Positive Organizational Scholarship, Berrett-Koehler, San Francisco, pp. 3-13.

Carroll, A. G. (1974), "The four faces of corporate citizenship", Business and Society Review, Vol. 100 No. 1, pp. 1-7. DOI: http://dx.doi.org/10.1111/0045-3609.00008

Chitsaz-Isfahani, A., Boustani, H. R. (2014), "Effects of Talent Management on Employees Retention: The Mediate Effect of Organizational Trust International", Journal of Academic Research in Economics and Management Sciences, Vol. 3 No. 5, pp. 114-128.

Chodorek, M. (2012), "The Place and Role of Talent Management in the Positive Organizational Potential: An Empirical Study of Companies Operating in Poland", Competition Forum, American Society for Competitiveness Publication, Vol. 10 No. 2, pp. 15-27.

Christensen, R. N. (1997), "Where is Human Resources?", in: Ulrich, D., Losey, M. R., Lake, G. (Eds.), Tomorrow's HR Management, John Wiley and Sons, New York, pp. 18-24.

Coase, R. H. (1937), “The Nature of the Firm”, Economica. New Series, Vol. 4 No. 16, pp. 386-405. DOI: http://dx.doi.org/10.1111/j.1468-0335.1937.tb00002.x

Collings, D. G., Mellahi, K. (2009), "Strategic talent management: A review and research agenda", Human Resource Management Review, Vol. 19 No. 4, pp. 304-313. DOI: http://dx.doi.org/10.1016/j.hrmr.2009.04.001

Crane, A., Matten, D. (2004), Business Ethics, Oxford University Press, Oxford.

Crane, A., Matten, D. (2007), Business Ethics, Oxford University Press, Oxford.

European Parliament, (2011), EU Multi Stakeholder Forum on Corporate Social Responsibility, available at: http://ec.europa.eu/DocsRoom/documents/8774/attachments/1/ trans lations/en/renditions/native (accessed 01 September 2015). 
Friedman, M. (1970), “The Social Responsibility of Business is to Increase its Profits", New York Times Magazine, September 13: 32-33, pp. 122-124.

Gandossy, R., Kao, T. (2004), "Talent wars: Out of mind, out of practice", Human Resource Planning, Vol. 27 No. 4, pp. 15-19.

Geyskens, I., Steenkamp, J. B. E. M., Kumar, N. (2006), "Make, Buy, or Ally: A Transaction Cost Theory Meta-Analysis", Academy of Management Journal, Vol. 49 No. 3, pp. 519-543. DOI: http://dx.doi.org/10.5465/AMJ.2006.21794670

Ghoshal, S., Moran, P. (1996), "Bad for Practice: A Critique of the Transaction Cost Theory", The Academy of Management Review, Vol. 21 No. 1, pp. 13-47. DOI: http://dx.doi.org/10.5465/AMR.1996.9602161563

Gond, J. P., Igalens, J., Swaen, V., El Akremi, A. (2011), “The Human Resources Contribution to Responsible Leadership: An Exploration of the CSR-HR Interface", J Bus Ethics, Vol. 98 No. 1, pp. 115-132. DOI: http://dx.doi.org/10.1007/ s10551-011-1028-1

Grayson, D. (2010), "W poszukiwaniu nowej definicji wartości”, Harvard Business Review Polska, dodatek „Odpowiedzialny Biznes 2010”, pp. 10-16.

Hodges DeTuncq, T., Schmidt, L. (2013), "Examining integrated talent management", $T+D$, Vol. 67 No. 9, pp. 30-35.

Hollender, J., Breen, B. (2010), The responsibility revolution. How the next generation of businesses will win, Jossey-Bass, A Wiley Imprint, San Francisco.

Hollender, J., Brenn, B. (2010), "The Responsibility Revolution: How the Next Generation of Business Will Win”, in.: Bielewicz, A. (Ed.), Odpowiedzialność 2.0, Harvard Business Review Polska, dodatek "Odpowiedzialny Biznes 2010”, pp. 4-9.

Husted, B. W., Folger, R. (2004), "Fairness and Transaction Costs: The Contribution of Organizational Justice Theory to an Integrative Model of Economic Organization", Organization Science, Vol. 15 No. 6, pp. 719-729. DOI: http://dx.doi.org/10.1287/ orsc. 1040.0088

Jackson, S. E., Schuler, R. S. (1990), "Human resource planning: Challenges for industrial/ organizational psychologists", American Psychologist, Vol. 45 No. 2, pp. 223-239. DOI: http://dx.doi.org/10.1037/0003-066X.45.2.223

Jones, G. R., Hill, Ch. W. L. (1988), "Transaction cost analysis of strategy-structure choice", Strategic Management Journal, Vol. 9 No. 2, pp. 159-172. DOI: http:// dx.doi.org/10.1002/smj.4250090206

Jones, T. (1995), "Instrumental stakeholder theory: A synthesis of ethics and economics", Academy of Management Review, Vol. 20 No. 2, pp. 404-437. DOI: http://dx.doi. org/10.5465/AMR.1995.9507312924

Kang, Y. Ch., Wood, D. J. (1995), "Before-Profit Social Responsibility: Turning the Economic Paradigm Upside Down", in: Nigh, D., Collins, D. (Eds.), Proceedings of the Sixth Annual Meeting of the International Association of Business and Society, IABS, Vienna, pp. 408-418.

Kotler, P., Lee, N. (2005), Corporate Social Responsibility. Doing the Most Good for Your company and your cause, Wiley and Sons, New Jersey.

Lewis, R. E., Heckman, R. J. (2006), “Talent management: A critical review”, Human Resource Management Review, Vol. 16 No. 2, pp. 139-154. DOI: http://dx.doi. org/10.1016/j.hrmr.2006.03.001 
SUCCESSFUL TALENT

MANAGEMENT

THROUGH POSITIVE

Adrian Pyszka

Daniel Gajda
Majeed, A. (2013), "Application of Business Process Through Talent Management: An Empirical Study", Journal of Marketing and Management, Vol. 4 No. 2, pp. 46-68.

Maon, F., Lindgreen, A., Swaen, V. (2009), "Designing and Implementing Corporate Social Responsibility: An Integrative Framework Grounded in Theory and Practice", Journal of Business Ethics, Vol. 87 No. 1, pp. 71-89. DOI: http://dx.doi.org/10.1007/ s10551-008-9804-2

Mehta, A. (2011), "Human Capital Management: A Comprehensive Approach to Augment Organzational Performance", Review of Management, Vol. 1 No. 2, pp. 44-57.

Michaels, E., Handfield-Jones, H., Axelrod, B. (2001), The war for talent, Harvard Business School Press, Boston.

Midttun, A. (2007), "Corporate responsibility from a resource and knowledge perspective Towards a dynamic reinterpretation of $\mathrm{C}(\mathrm{S}) \mathrm{R}$ : are corporate responsibility and innovation compatible or contradictory?", Corporate Governance, Vol. 7 No. 4, pp. 401-413.

Midttun, A., Dirdal, T., Gautesen, K., Omland, T., Wenstøp, S. (2005), "Integrating Corporate Social Responsibility and Other Strategic Foci in a Distributed Production System - A Transaction Cost Perspective on the North Sea Offshore Petroleum Industry", BI Norwegian School of Management, Research Report 11/2005.

Nord, W. R., Riggs Fuller., S. (2009), "Increasing Corporate Social Responsibility Through an Employee-centered Approach", Employment Response Rights Journal, Vol. 21 No. 1, pp. 279-290. DOI: http://dx.doi.org/10.1007/s10672-009-9126-2

Paauwe, J., Boselie, P. (2003), 'Challenging 'strategic HRM' and the relevance of the institutional setting”, Human Resource Management Journal, Vol. 13 No. 3, pp. 56-70. DOI: http://dx.doi.org/10.1111/j.1748-8583.2003.tb00098.x

Phillips, D. R., Roper, K. O. (2009), "A framework for talent management in real estate", Journal of Corporate Real Estate, Vol. 11 No. 1, pp. 7-16.

Pilbeam, S., Corbridge, M. (2002), People resourcing. HRM in practice, $2^{\text {nd }}$ ed., Prentice Hall, New Jersey.

Porter, M. E., Kramer, M. R. (2006), "Strategy and society: the link between competitive advantage and corporate social responsibility", Harvard Business Review, Vol. 84 No. 12 , pp. 78-92.

Porter, M. E., Kramer, M. R. (2011), “Creating Shared Value. How to reinvent capitalism - and unleash a wave of innovation and growth", Harvard Business Review, No. 1-2, pp. $1-17$.

Pyszka, A. (2013), "Corporate Social Innovation: How to Create Value by Doing the Right Things?", in: Nalepka, A., Ujwary-Gil, A. (Eds.), Business And Non-Profit Organizations Facing Increased Competition And Growing Customers Demands, Wydawnictwo i Drukarnia Nova Sandec (Wyższa Szkoła Biznesu - National-Louis University), pp. 21-34.

Pyszka, A., Piłat, M. (2011), “Applying Trompenaars typology of organizational culture to implementation of CSR strategy", Journal of Intercultural Management, Vol. 3 No. 2, pp. 113-125.

Rothwell, W. J. (1994), Effective succession planning: Ensuring leadership continuity and building talent from within, Amacom, New York. 
Sharp, Z., Zaidman, N. (2010), "Strategization of CSR", Journal of Business Ethics, Vol. 93 No. 1, pp. 51-71. DOI: http://dx.doi.org/10.1007/s10551-009-0181-2

Silvaab, P., Cooray, R. (2014), "Building Human Capital in Organizations through Corporate Social Responsibility - A holistic coaching approach", Procedia - Social and Behavioral Sciences, Vol. 159 No. 1, pp. 753-758.

Smart, B. D. (1999), Topgrading: How leading companies win by hiring, coaching, and keeping the best people, Penguin Group, New York.

Stahl, G. K., Björkman, I., Farndale, E., Morris, S. S., Paauwe, J., Stiles, P., Trevor, J., Wright, P. M. (2012), "Six Principles of Effective Global Talent Management", MIT Sloan Management Review, Vol. 53 No. 2, pp. 25-32.

Tabor, J. (2013), Zarzqdzanie talentami w przedsiębiorstwie: koncepcje, strategie, praktyka, Poltext, Warszawa.

Thornton, (2008), Corporate Social Responsibility: a necessity not a choice, Grant Thorton International Business Report.

Tucker, E., Kao, T., Verma, N. (2005), "Next-generation talent management: Insights on how workforce trends are changing the face of talent management", Business Credit, Vol. 107 No. 7, pp. 20-27.

Ulrich, D., Smallwood, N. (2002), "Seven Up”, available at: http://www.cipd.co.uk/pm / peoplemanagement/b/weblog/archive/2013/01/29/6753a-2002-05.aspx (accessed 01 September 2015).

Vladescu, A. (2012), "The possibility of implementing talent management in the public sector", Management and Marketing Challenges for the Knowledge Society, Vol. 7 No. 2, pp. 351-362.

Waddock, S., Bodwell, Ch. (2007), Total Responsibility Management, Greenleaf Publishing, Sheffield.

Wheeler, D., Sillanpää, M. (1997), The Stakeholder Corporation. A blueprint to maximizing stakeholder value, Pitman Publishing, London.

Williamson, O. E. (1998), Ekonomiczne Instytucje kapitalizmu. Firmy, rynki, relacje kontraktowe, PWN, Warszawa.

Williamson, O. E. (2010), "Transaction Cost Economics: The Origins", Journal of Retailing, Vol. 86 No. 3, pp. 227-231. DOI: http://dx.doi.org/10.1016/j.jretai.2010.07.006

Zink, K. J. (2008), Corporate Sustainability as a Challenge for Comprehensive Management, Physica-Verlag, A Springer Company, Heilderberg. 